Ingura or Wanindijaugwa of Groote Eylandt, off the northern coast of Australia. The account is based on about four months research in 1941, at which time the population numbered between 300 and 350 individuals. They were organized into eleven localized totemic patriclans, these being grouped into unnamed exogamous moieties.

The major argument is that 'gerontocracy' (the practice of marrying young girls to considerably older men) leads to the abandonment of the general Australian rule of bilateral cross-cousin marriage, and thence to the adoption of the matrilateral rule. The author tries to demonstrate this by assessing the ages of individuals and relating the resultant age-distribution by sex to possible rules of marriage. He shows, for example, that there is an average difference of 15 years between 'full cross-cousins', the patrilateral being the older. It is therefore argued that under gerontocracy this relative could not be married, so that neither patrilateral nor bilateral cross-cousin marriage is possible in this society. But this conclusion relates only to first cousins, whereas typically in a lineal descent system it is a more extensive class of relative, not defined primarily in genealogical terms, which is covered by the marriage regulations. If, then, we consider the ages of all members of the indigenous categories concerned, we have reason to expect a different situation; and in fact the case of individual No. 6, selected solely according to sex (male) and age (23), gives the following results: seven female patrilateral crosscousins, average age 37; fifteen matrilateral, average age 36. If this case is typical, as on general grounds we may presume it to be, it shows that it is simply the author's European prejudice towards a genealogical definition of status which frames his argument and lends it apparent support.

Moreover, the account of the system is defective. As might be expected with such a short investigation, and an imperfect knowledge of the language, the ethnography is slight and unsatisfactory. The relationship terms seem, on the whole, to indicate an eight-section system, but the genealogical specifications reported are insufficient to establish the precise features of the actual system. Certain positions are not covered by the specifications, and there is an untypical distinction of patrilateral from matrilateral cross-cousin. It is clear, however, that the form of social classification is, contrary to the author's odd assertion, neither 'Kariera' nor 'Karadjeri' (he thinks the 'Aranda' type of system never existed). Also, the normal marriage is said to be with the mother's mother's brother's daughter's daughter who is a 'distant' mother's brother's daughter; but this cannot be reconciled with the system apparently framed by the terminology. Moreover, the abundant tabular data, occupying 220 pages of the book, are no substitute for genealogies, details of group. composition, and territorial distribution, let alone the indigenous ideology, and they cannot yield the evidence which is necessary to structural investigations of the kinds suggested by the author's argument.

In view of the interest of the issues he deals with, Dr. Rose's study is particularly exasperating. His record of ages is precisely the kind of exact evidence which is essential to the comprehension of Australian societies, and he is right to deplore its absence from other accounts; but without a comprehensive structural examination, conducted primarily in terms of the categories employed by the people themselves, this record is of depressingly little sociological use.
It is possible, however, that it may serve certain purposes; and the work also includes percipient and forceful observations on a variety of other topics in the study of aboriginal Australian society (see, for example, his criticisms of Radcliffe-Brown's statements about the Kariera). Inadequate though it must be judged, and fallacious as its central argument almost certainly is, Dr. Rose's monograph is a singular (if eccentric) contribution to the field and deserves a place in any library of social anthropology.

R. NEEDHAM

\section{SOME ASPECTS OF HAMATOLOGY}

Lectures on Haematology

Edited by F. G. J. Hayhoe. Pp. viii $+247+24$ plates. (Cambridge: At the University Press, 1960.) 60s. net.

HE chapters in this book represent a course of thirteen lectures delivered to an audience of postgraduate clinicians and medical research workers. Most of the information has been published elsewhere, but this is in no sense a text-book of hæmatology. Each chapter is a survey, by an expert, of some rapidly expanding or controversial topic in the field. The accounts are of necessity brief, and only some of the most recent work is covered in detail. A good bibliography at the end of each chapter brings in the earlier literature.

The first five chapters deal with abnormalities in production and reactions of erythrocytes. J. V. Dacie writes on acquired hæmolytic anæmia, W. M. Davidson on iron metabolism and iron-deficiency anæmir and R. H. Girdwood on the pathogenesis and differential diagnosis of megaloblastic anæmias. The hazards of blood transfusion are discussed by G. T. Discombe, and J. C. White gives an account of hæmoglobin variants.

Although these chapters are directed primarily to the audience concerned they will provide useful information for a much wider circle of readers. Anyone concerned with the preparation or administration of blood for transfusion would profit from reading this entertainingly written and eminently practical account of the hazards involved. Especially since, as the author mentions, there is at present no comprehensive review of the subject in the English language.

Chapters 6-10 deal with various aspects of leukæmia. F. G. J. Hayhoe, who is also the editor of the book, considers the clinical and eytological recognition and differentation of the leukæmias. G. Wetherley-Mein writes on the myeloproliferative syndromes, and R. Doll on the incidence of leukæmia and the significance of environmental factors in its causation. The chemotherapy of leukæmia is discussed, as a practical problem, by D. A. G. Galton, and H. E. M. Kay writes on the potentialities of marrow transplantation in the treatment of leukæmia.

The last three chapters deal with abnormalities in hæmostasis. R. M. Hardisty discusses the contribution of blood and blood vessels in the hæmostatic process. Congenital and acquired disorders of coagulation are reviewed by G. I. C. Ingram and the pathogenesis of purpura by J. F. Ackroyd.

A great merit of the book is that it is easy to read, for in most cases the lively and personal approach of a lecture has survived in the printed account.

M. E. Nutr 